\title{
The Correlation between Concept Mastery and Stage of Moral Reasoning Student Using Socio-scientific Issues on Reproductive System Material
}

\author{
Tri Ayu Lestaria ${ }^{a}$, Saefudin ${ }^{\mathrm{b}}$, Didik Priyandoko \\ Department of Biology, Indonesia University of Education, Jl. Dr. Setiabudi No. 229, Bandung 40154, Indonesia \\ Corresponding e-mail: : tari.talvr03@gmail.com
}

\begin{abstract}
This research aims to analyze the correlation between concept mastery and moral stages of students. The research method using a correlational study with stratified random sampling technique. The population in this research is all of eleventh grade students in Senior High School Bandung. Data were collected from 297 eleventh grade students of three Senior High School in Bandung with use the instrument in the form of examination and stage of moral reasoning questionnaire. The stage of moral reasoning in this research consists of two student's moral reasoning categories based on 16 questionnaire as the indicators from Jones et al. (2007). The results of this research shows that the average of eleventh grade student's moral reasoning stage is the advanced stage. The results of this research shows that the concept mastery and the stage of moral reasoning indicates that there are $0.370 \mathrm{of}$ a positive correlation. This research provides an overview of eleventh grade student about concept mastery and stage of moral reasoning using socio-scientific issues.
\end{abstract}

Keyword: Concept Mastery, Moral Reasoning Stage, Socio-scientific Issues

\section{INTRODUCTION}

Biological Sciences is still growing along with the new researches and discoveries which is related to the development of science and technology such as in molecular biology and biotechnology. These technological advancements have positive and negative effects on life. It caused by technology makes the practical problems and the difficulties which faced by human beings can be solved. The positive effect of the biological science development is the use of in vitro fertilisation for the couples who are difficult to get a child while the negative effect of technological development appears which marked by the changes of human civilization such as the shifts of human values as well as those associated with various ideational effects.

The spread of moral issues among the teenagers such as the use of drugs, pornography, violation, and abortion have become social problems which cannot be solved completely until now. This condition is very concerning the community, especially parents and teachers (educators) because the suspects and their victims are teenagers, especially students and colleges. The teenagers naturally have a very large sexual drive, mostly encouraged to have sex experiences. If there is no reins, the teenagers can fall into the prostitution, free sex, premarital sex and other negative consequences. When those cases happen and lead to pregnancy, the possibility of a shortcut is doing abortion. Premarital pregnancy in the range age of 17-18 years is higher than the range age of 19 years and more [7]. Until January 2011, five girls per day is an average girls' admit that they have sex experience before marriage. Their age during pregnancy is varies, start from eighth grade students until colleges.

The real education gives the biggest contribution toward the current situation of moral shift. Krech states that knowledge is one of the factors that can shape moral development. A knowledge of abortion and the effects itself can shape a strict attitude of students to avoid it [6]. Biological sciences that have been studied from basic education to higher education by students should be able to provide a solid foundation for the 
development of student assessments of good or bad situations for the sake of themselves.

The education about free-sex and abortion have a close relevance with biology, specifically in the chapter "Reproductive System". A moral teenager will automatically appear in his/her judgment or moral reasoning as well as in his/her good behaviour with the etic [4]. Observing the currently condition of many moral deviation cases among the children and the teenagers make the tasks of teachers or educators and pedagogists of moral education to be more complicated.

An assessment of the good and bad things which a person has, it affects the decision-making in informal reasoning. That assessment will be influenced by his/her moral development.

The process of preparing and evaluating the arguments rationally can be valued through the assessment of moral reasoning. Socio-scientific issues are compatible for the application of personal attitude assessment because those issues are complex, open-minded and controversial [5]. The individual of moral assessment are influenced by many things such as emotional considerations, social considerations, personal experiences, and the complexity of perceptions. Decision-making about socio-scientific issues involves a process of innegotiation of two contradictory statements, a truth evaluation of a statement, and a risk allegation in accordance with the available evidence.

Technological advancement and the development of science make the issues which spread in the society more complex. If a person has informal reasoning that does not develop, then it will be difficult to answer and make decisions about socio-scientific issues. According to that statements, the researcher does the research about the concept mastery's and the stage of reasoning's senior high school students.
Table 1 Instruments of Moral Reasoning Stage According to Jones et al. (2007)

\begin{tabular}{|c|c|c|}
\hline $\begin{array}{l}\text { Level of } \\
\text { Moral } \\
\text { Reasoning } \\
\text { Stage } \\
\end{array}$ & $\begin{array}{l}\text { Moral } \\
\text { Reasoning } \\
\text { Stage } \\
\text { Indicator } \\
\end{array}$ & Indicator Description \\
\hline \multirow[b]{2}{*}{ Beginner } & $\begin{array}{l}\text { Short-term } \\
\text { effects }\end{array}$ & $\begin{array}{l}\text { Arguments presented by } \\
\text { students are based on } \\
\text { personal interests } \\
\text { The arguments presented } \\
\text { by the students contain } \\
\text { short-term effects that } \\
\text { may occur from the issue }\end{array}$ \\
\hline & $\begin{array}{l}\text { Arguments } \\
\text { using daily } \\
\text { language } \\
\text { The } \\
\text { argument } \\
\text { presented } \\
\text { without } \\
\text { approach or } \\
\text { only use } 1 \\
\text { approach }\end{array}$ & $\begin{array}{l}\text { The argument presented } \\
\text { based-on the general } \\
\text { knowledge of the students } \\
\text { without any background } \\
\text { knowledge. }\end{array}$ \\
\hline \multirow{3}{*}{ Advanced } & $\begin{array}{l}\text { Long-term } \\
\text { impact }\end{array}$ & $\begin{array}{l}\text { The arguments presented } \\
\text { by students based-on the } \\
\text { interests of general and } \\
\text { wide society. } \\
\text { The argument presented } \\
\text { by the students contains } \\
\text { the possible long-term } \\
\text { effects of the issue }\end{array}$ \\
\hline & $\begin{array}{l}\text { based on } \\
\text { scientific } \\
\text { knowledge }\end{array}$ & $\begin{array}{l}\text { The arguments are based } \\
\text { on the knowledge which } \\
\text { possessed by the students }\end{array}$ \\
\hline & $\begin{array}{l}\text { The } \\
\text { argument } \\
\text { uses } 2 \text { or } \\
\text { more } \\
\text { approaches }\end{array}$ & $\begin{array}{l}\text { The argument presented } \\
\text { uses two or more } \\
\text { approaches in the } \\
\text { economic, social, cultural, } \\
\text { political or religious } \\
\text { fields. }\end{array}$ \\
\hline
\end{tabular}

\section{EXPERIMENTAL METHOD}

The method used in this research is Correlational Research. Correlational research describes the level 
of correlation between two or more quantitative variables by using correlation coefficients [1]. This research was analyzed by using Spearman's Correlation Test. Based on the design of this research, the variables used are the stage of moral reasoning as a dependent variable while the concept mastery as independent variables.

Population in this research is all of eleventh grade students in Senior High School Bandung. The samples were selected in this research is using stratified random sampling technique. The sample begins with determining the clusters of Senior High School in Bandung and selecting one school from each cluster randomly. The next stage is choosen from two until three sample classes of eleventh grade representatives in each school. Therefore, the total sample used is 297 eleventh grade students from three schools.

The stage of moral reasoning was measured through a questionnaire which consist of the stage of moral reasoning according to Jones et al. (2007) [2]. The questionnaire consists of 16 questions about socio-scientific issues (abortion, transgender, in vitro fertilisation and surrogate mother). The test of moral reasoning stage is given to eleventh grade students of Senior High School in Bandung. In this research, the concept mastery of Biology is obtained from the result of reproduction system test. This data are obtained from eleventh grade student of Senior High School in Bandung

\section{RESULT AND DISCUSSION}

\subsection{Result}

The correlation test between the concept mastery of Biology and the stage of moral reasoning was analyzed and tested using Microsoft Excel 2013 and SPSS 23 program. The test begins with Kolmogorov-Smirnov's Normality Test and it obtained the data which are not distributed normally with a significant number which is less than 0.025 . Therefore, the data were tested by NonParametric Test i.e One-Sample KolmogorovSmirnov test (Table 2). The results obtained from the statistical test for concept mastery data is 0.109 with a significant number is 0.00 . The results for the stage of moral reasoning data is 0.423 with a significant number is 0.00 . The test in this research is a two-way test, so that the result is determined with a significant is more than 0.05 . The data which obtained from this test indicate that the significant level is less than 0.05 , so that the data is not normally distributed.
Table 2. Kolmogorov-Smirnov One Sample Test

\begin{tabular}{lcc}
\hline & $\begin{array}{c}\text { Concept } \\
\text { Mastery }\end{array}$ & $\begin{array}{c}\text { Moral } \\
\text { Reasoning } \\
\text { Stage }\end{array}$ \\
\hline $\begin{array}{l}\text { Kolmogorov- } \\
\text { Smirnov }\end{array}$ & 0.109 & 0.423 \\
$\begin{array}{l}\text { Asymp. Sig. (2- } \\
\text { tailed) }\end{array}$ & 0.00 & 0.00 \\
\hline
\end{tabular}

The analysis of the correlation between concept mastery and the stage of moral reasoning from 297 eleventh grade students was tested statistically by using Spearman's Correlation Test. The results of this test indicate that there is a correlation between both of them in the rate 0.370 (Table 3). The significant level obtained is 0,000 which indicates a significant that less than 0.025 . Therefore, it can be accepted that there is a correlation between the concept mastery and the stage of moral reasoning. A positive number indicates the direction of correlation between the two variables that if the result of concept mastery is good then the result of moral reasoning stage will be equal.

Table 3. Spearman's Correlation Test between Concept Mastery and Moral Reasoning Stage

\begin{tabular}{cc} 
Mastery and Moral Reasoning Stage \\
\hline \\
$\begin{array}{c}\text { Concept Mastery and } \\
\text { Moral Reasoning Stage }\end{array}$ \\
\hline Correlation & 0.370 \\
coefficient & \\
Sig. (2-tailed) & 0,000 \\
$\mathrm{~N}$ & 297 \\
\hline
\end{tabular}

The result of concept mastery reproduction system in eleventh grade has a range around 68 to 90 with a minimum value is 44 and a maximum value is 96 . The average value of concept mastery is 78 with a standard deviation is 12 . Based on Graph 1 about distribution concept mastery, it is known that the range values which have got by students are in the range of 75 and 85 . The concept mastery result of eleventh grade students are categorized into lower rank $(<67)$, middle $(67-90)$, and upper $(>90)$. Based on the results of this research, it obtained the lower rank is $14 \%$, medium is $68 \%$, and high is $118 \%$. 


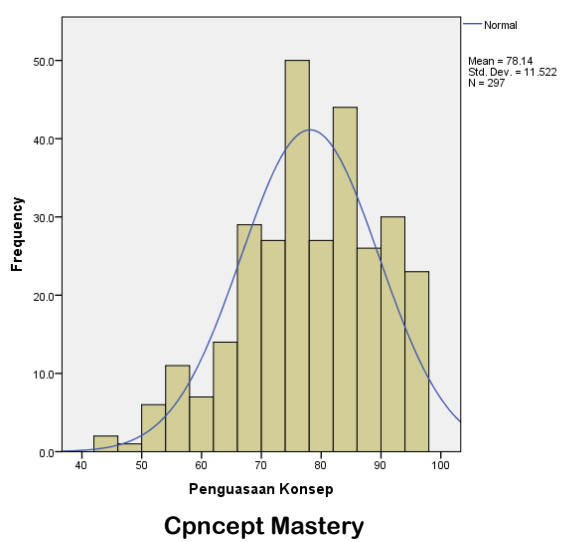

Graph 1. The Distribution of Concept Mastery Test Result in Eleventh Grade

The answer about the question of socioscientific issues for measuring the stage of moral reasoning is categorized into the advanced stage and the beginners. 297 of eleventh grade students have a lot result of distribution in advanced stage (Graph 2 ). The totally sample of students with an advanced stage is amounted to 196 students $(66 \%)$ and for the beginner stage is amounted to 101 students (44\%).

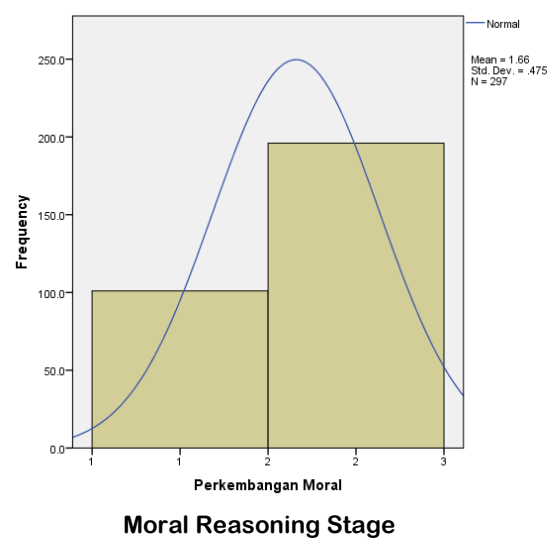

Graph 2. The Distribution of the Moral Reasoning Stage Test Result in Eleventh Grade

According to the cluster each school i.e high cluster ("A" Senior High School), middle cluster ("B" Senior High School), and low cluster ("C" Senior High School), it obtained the average result which shown in Table 4 . The average result of concept mastery and stage of moral reasoning which mostly appear in schools A, school B, and school C is not much different.
Table 4. The Average Result of Concept Mastery and Moral Reasoning Stages Which Mostly Appears Based On School

\begin{tabular}{ccc}
\hline School & $\begin{array}{c}\text { Concept } \\
\text { Mastery } \\
(\text { Mean) }\end{array}$ & $\begin{array}{c}\text { Moral Reasoning Stage } \\
\text { (Modus) }\end{array}$ \\
\hline A & 88 & Advanced \\
B & 79 & Advanced \\
C & 71 & Advanced \\
\hline
\end{tabular}

\subsection{Discussion}

Concept mastery is very important in learning because it makes the learners can improve their intellectual skill and the problems which faced by them can be solved, and make learning becomes meaningful. A person can be considered as the expert one if she/he really understand about the concept which she/he learn, so that she/he can explain by using his own words in accordance with the knowledge she/he possesses, but does not change the meaning. Moral reasoning stage of students involves the educational process undertaken in their environment. The educational institution is the place to control over the characteristic and quality of individual life which derived from an interactive cause and effect between human behaviour and the environment. A person who has a good result of concept mastery and its result of moral reasoning stage will be equal if only the moral judgement about socio-scientific issues is rationally arranged in his argument.

It is related to the correlation test between concept mastery and the stage of moral reasoning i.e the correlation coefficient is 0.370 . The coefficient indicates that there is a positive correlation where if the result of concept mastery is good then the result of moral reasoning stage will be equal. Conversely, if the result of concept mastery is low then the result of moral reasoning stage will be equal. The data indicates that the students, especially eleventh grade students still have not maximally implemented the concept mastery. In the fact, concept mastery is important to be developed into various levels of students and inculcated early to provide the provision of the moral reasoning stage of the student. The importance of the assessment of this moral stage is also to illustrate that the learning process involves the cultivation of moral values. It caused by the assessment of student's moral reasoning stage can be considered as the good ones 
if only their action is accompanied by beliefs and knowledge of the kindness. A person needs to process an experience which related to him/herself and others to understand and believes her/his experience. An assessment of the good and bad things affects decision-making in informal reasoning. The assessment of a person will be influenced by his moral development.

The categories which outlined within the framework of moral reasoning stage is basically cover all the fundamental aspects of the learning process. The category of moral reasoning stage does not mean that it should apply all categories in one situation. For example, if students are given a problems such as abortion, so the student is expected to apply the moral values that they have based on the interests of society, long-term effects, and based on the knowledge that they have, especially Biology. Some students have a high value of concept mastery but the stage of moral reasoning is still in the beginner category. It caused by the students has not been able to apply concept mastery which they already have towards the real problems in their environment.

The researcher founds the consistency of students in answering questions which related to socio-scientific issues to assess their moral stages. The consistency result of the students was obtained is $239(80 \%)$ students answered consistently to the question about themselves, gender differences, family and society. The most consistent student means that the students answer the different questions for themselves, gender differences and community is $58(20 \%)$ students. It shows that the thoughts and attitude that students will be related to the answer of their argument when they are facing the problems about socio-scientific moral issues.

As many as $76 \%$ of the 297 students gave long-term arguments about the possibility of a given socio-scientific issue. It means students can give the solution of the problems not only now but also in the future. As many as $80 \%$ of the 297 students give an argue using two or more approaches. The argument presented by the student uses approaches in religion, biology, economics and law fields. The important thing to understand is that the effect of conceptualization on the students' moral reasoning can not affect abruptly. The process of developing moral reasoning is a process of transferring roles, i.e the process of development toward a more comprehensive, more differentiated and more balanced than the previous structure [3]. A person who has a high moral reasoning stage can view his problem from multiple points of view and solves it by taking many factors as consideration. The moral sense of children in the range of ten or eleven years old is different from the older children based on their knowledge and experience.

\section{CONCLUSION}

The formation of good concept mastery will help the students to get a good stage of moral reasoning in accordance with the results of correlation analysis between both of them which indicate a positive correlation. Furthermore, it is expected that teachers and students can understand the importance of biology learning which involve moral character education.

\section{ACKNOWLEDGMENTS}

On this occasion, the author would like to express his gratitude to Drs. Iwan Setiawan as headmaster in 24 senior high school Bandung, $\mathrm{Hj}$. Heniyati, M. M. Pd as headmaster in 20 senior high school Bandung and Saptana Surahmat, S. Pd as curriculum head in 10 senior high school Bandung that has given permission to the researchers to conduct test instruments and conduct research.

\section{REFERENCES}

Fraenkel, et al. (2012). How to Design and Evaluate Research in Educatio. New York: McGraw-Hill.

Jones, A., Mckim, A., Reiss, M., Ryan, B., Buntting, C., Saunders, K., ... Conner, L. (2007). Research and Development of Classroom-Based Resources for Bioethics Education in New Zealand. Hamilton, NZ: Wilf Malcolm Institute of Educational Research, School of education, the University of Waikato.

Kohlberg, L. (1984). The Psychology of Moral Development: The Nature and Validity of Moral Stages. Essays on Moral Development. 2.

Malti, T., Gasser, L., Helfenfinger, E., (2010). Children's Interpretive Understanding, Moral Judgments, and Emotion Attributions: Relations to Social Behavior. British Journal of Developmental Psychology. 28, 275-292.

Sadler, TD, and Donnely LA (2007). Socioscientific Argumentation: The Effects of Content Knowledge and Morality. International Journal of Science Education, 28, 1463-1488.

Suroso, A. Y. (2008). Manajemen Alam Sumber Pendidikan Nilai. Bandung: Mughni Sejahtera.

Zalbawi, Soenanti. (2002). Masalah Aborsi Dikalangan Remaja. Media Litbang Kesehatan. XII, 